\title{
URBAN EXPANSION OF ERBIL AND THE EFFECTS OF ENVIRONMENTAL DURING THE PERIOD 1947-2017 (A STUDY IN THE GEOGRAPHY OF CITIES)
}

\author{
DR. NISHAN S. M \\ Dept. of Geographic, College of education, University of Duhok, Kurdistan Region -Iraq
}

(Received: December 18, 2018; Accepted for Publication: March 8, 2019)

\section{1-INTRODUCTION}

$\mathbf{T}_{\mathrm{i}, \mathrm{s}}$ The phenomenon of urban expansion and its extension at the expense of agricultural land is a major challenge for most countries of the world, especially, for developing countries whose population is growing at a high rate. And the consequent pressure on resources, especially, agricultural land surrounding the communities.

So, it was therefore necessary on states to plan to eliminate this problem and put an end to this phenomenon of urbanization on agricultural land .Through proper planning and study of the phenomenon in all its aspect in order to find right solution to preserve the environment and vital systems surrounding the communities.

The natural factor of topography plays a major role in the spread of Urbanization because plain areas are the most suitable areas for humanitarian activities, making the population more concentrated than other urbanism form.

The easy of expansion of cities in the plain areas other than mountains areas leads to the excessive consumption of agricultural land which decrease size year after year.

The City of Erbil has witnessed a large urban expansion and extended its area at the expense of neighboring agricultural lands.

This expansion has brought about significant changes in the natural landscaping of fertile agricultural land and transformation into human components (communities) (housings, buildings, Streets, etc.Resulting in many environmental problems.

\section{2-Study problem;}

The problem is: What are the environmental impacts of urbanization of Arbil?

3-Study Hypothesis;

1-There is a relationship between both urban expansion
2-The city of Erbil possesses the elements of urban expansion

\section{3- Study Aims;}

The study aims at explaining the Urban expansions witnessed in the City of Erbil during the period (1947-2017) through different stages and aims to identify the factors that influenced this expansion with showing the directions of the trends and the most important problems that emerged as the results of that expansion.

\section{4-Study Methods;}

The search will based on comparative analysis method based on recent and old data while analyzing data and information related to the study areas for the purpose of variable data obtained in the environment of the region.

The nature of study will necessitate to divide it to the following divisions (axis)

1. The definition of the City of Erbil and its environmental reality.

2. The development stages of the city of Erbil (Morphology of city).

3. Factors affecting (natural and economical and social) urban expansion of the city.

4. Geographical distribution of the expansion trends.

5. The most important environmental problems as the result of this expansion.

\section{THE LIMITS OF THE STUDY}

\section{The definition of Erbil city and its environmental reality: \\ We can define the city of Erbil and its environmental reality through the following points: \\ 1. The city of Erbil is the administrative center of Erbil governorate. The city of Erbil is located between the two latitudes (36: 07-36: 14) north and the longitudes (43: 56-44:07) to the east. Map No.1-}


The study site within the map of Iraq (map number1)

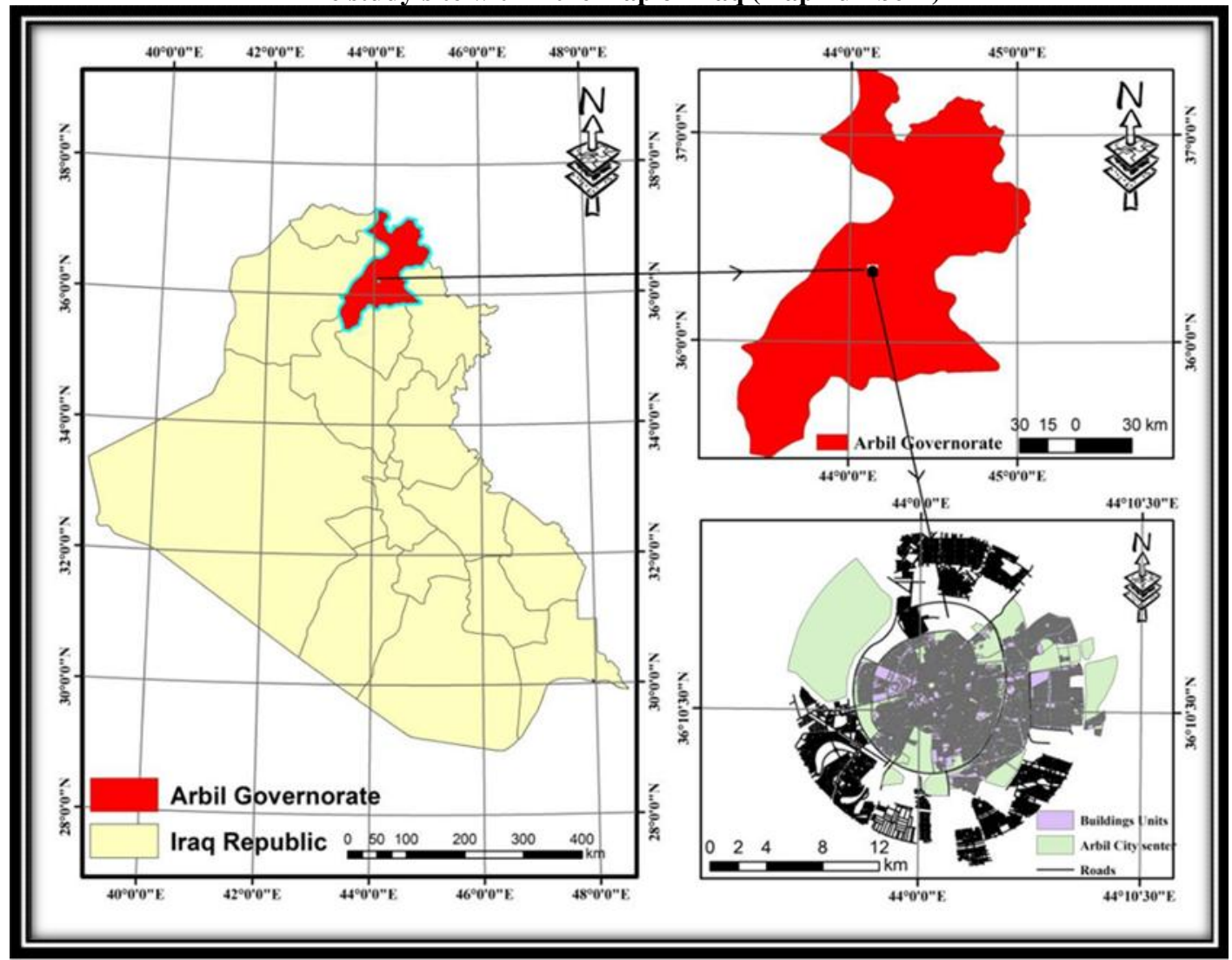

reference; the work of the researcher depending on the Ministry of Municipalities,

Urban planning directorate, part (GIS) map of Erbil 2017.

2. The city of Erbil is located in the area of plain areas (center of Erbil plain fertile) and the land in the location of the city from the northeast to the south-east and fall in the center of the city to (412 m) above sea level, with the exception of Erbil Castle in the center of the city, The city grew around it and expanded, as the citadel rises (26.5 $\mathrm{m})$ from the rest of the city (1)

3. The climate of the city of Erbil and the climate of the city's arid plain is characterized by a semiarid continental climate similar to the Mediterranean climate in terms of rainfall. It is a hot dry climate in the summer and mild in the winter. It is classified as a hot and dry summer (BSsh). According to kobben classified.(2)

\section{THE STAGES OF THE PROCESS OF URBAN EXPANSION OF THE CITY OF ERBIL}

Like other cities, Erbil has been subjected to urbanization at the expense of the surrounding land in order to meet the city's ever-growing population. This expansion can be explained by the following points:

\section{-The first stage;(1947-2000)}

1. The city of Erbil at the beginning of its inception and for a long time was a castle only. The city consisted of three main shops: (Tabakhanah, Serail and Tikkun). In the mid1930, Al-Mustufy was established in the northern part of the citadel and represents the first urban expansion of the city to the north. Then emerged the oldest three shops around the castle (Khanka and acceleration and Arabs). This was followed by the development of the commercial zone (caesarean section). After that, land use continued slowly until the late 1940 . The population of the city of Erbil in 1947 reached 25487 and the number of shops was 9.(3)

2. In 1950, the city saw an expansion in some of its main functions (commercial, residential and administrative), leading to urbanization to meet the needs of these jobs after their expansion. The 
result of this expansion was the emergence of new stores, Bringing the number of shops in the city of Erbil residential (11) locality, with a population of 3,9913.

3. The political factor plays a very large role in the growth of the population of the city of Erbil, which contributed to the increase in the population in the city of Erbil high rates due to the policies of displacement of rural population and the forced displacement of Kurdish citizens in the cities of Kirkuk and Khankin and Mandali during the years (1963-1974) The displacement of the Kurdish rural population in the areas bordering Iran has played a role in the increase in the proportion of the population of the city, as the Iraqi government concluded an agreement in Algeria with Iran in 1975 to evacuate the areas adjacent to Iran at a depth of $20 \mathrm{~km}$, All of these factors led to the rapid growth of the population in the city of Erbil. As a result, the number of shops in the city increased to (14) localities and the population reached (193558) (Population, according to the 1977 census) map no 2.(4)

4. The city of Erbil in (1987) significant changes in the growth and expansion of the population because of the negative consequences of the Iraq war - Iran, which has greatly affected the growth of migration from the border areas to the city of Erbil. The transfer of the University of Sulaymaniyah from the city of Sulaymaniyah to the city of Erbil in 1981 also contributed to the increase of the population growth of the study area and the expansion of urban areas and change the function and patterns of land use, as the number of shops to (44) locality, 30) by 10 years only, and the population of the city reached 423112 .

5. The city witnessed during the year (1992) major changes in economic, political and social aspects, including the uprising of the Kurdish people in 1991 and the transformation of the city of Erbil to the capital of the Kurdistan Region of Iraq, which gained the importance of administrative and political excellence. However, the city has witnessed a decline in urban activity due to several factors, especially the difficult economic conditions experienced by the city because of the double siege imposed on the region by the central government and the United Nations, as well as the factor of internal fighting, which adversely affected the economic activity and urbanization of the city.

6. The city witnessed a rise in the population in (2000), with the number of shops this year (47) locality, and the population (549839) people.

-The second stage;(2001-2017)

The number of residential shops in 2005 reached (59) locality, which means that during (4) years increased (12) locality, and the population reached (585961).(5)

Based on the above, it can be said that the population of the city of Erbil, has increased significantly during the period (1987-2005), as a result of the urban expansion witnessed by the city during that era, and can be attributed the reason of this expansion to several factors, including:

(A) The liberation of Iraq in 2003, which in turn affected the economic, political and social aspects of the city.

(B) the instability of the political situation in central and southern Iraq, which led to the orientation of large numbers of residents of the center and south to the study area.

(C) Expansion of commercial movement internally and externally, resulting in the import of construction materials in order to supply the rising urban movement.

(D) There is no balance in the distribution of services. The government's focus on the delivery of services to the city of Erbil has led to large numbers of rural and rural people moving towards the city of Erbil. This is due to the increase in the population of Erbil and the expansion of its area.

(E) The city witnessed (2017) growth and large urban expansion, increased in only five years (21) locality, with the number of shops from (59) to (80) residential neighborhood (6).

We conclude from the above that during the ten years only, ie through (2001-2017) the number of shops doubled, and the population reached (702812) people, all of which affected the change of the basic design of the city as a result of the urban process, as shown in the map No. 2 
Urban expansion of the city of Erbil through period( 1974-2017)(nap no 2)

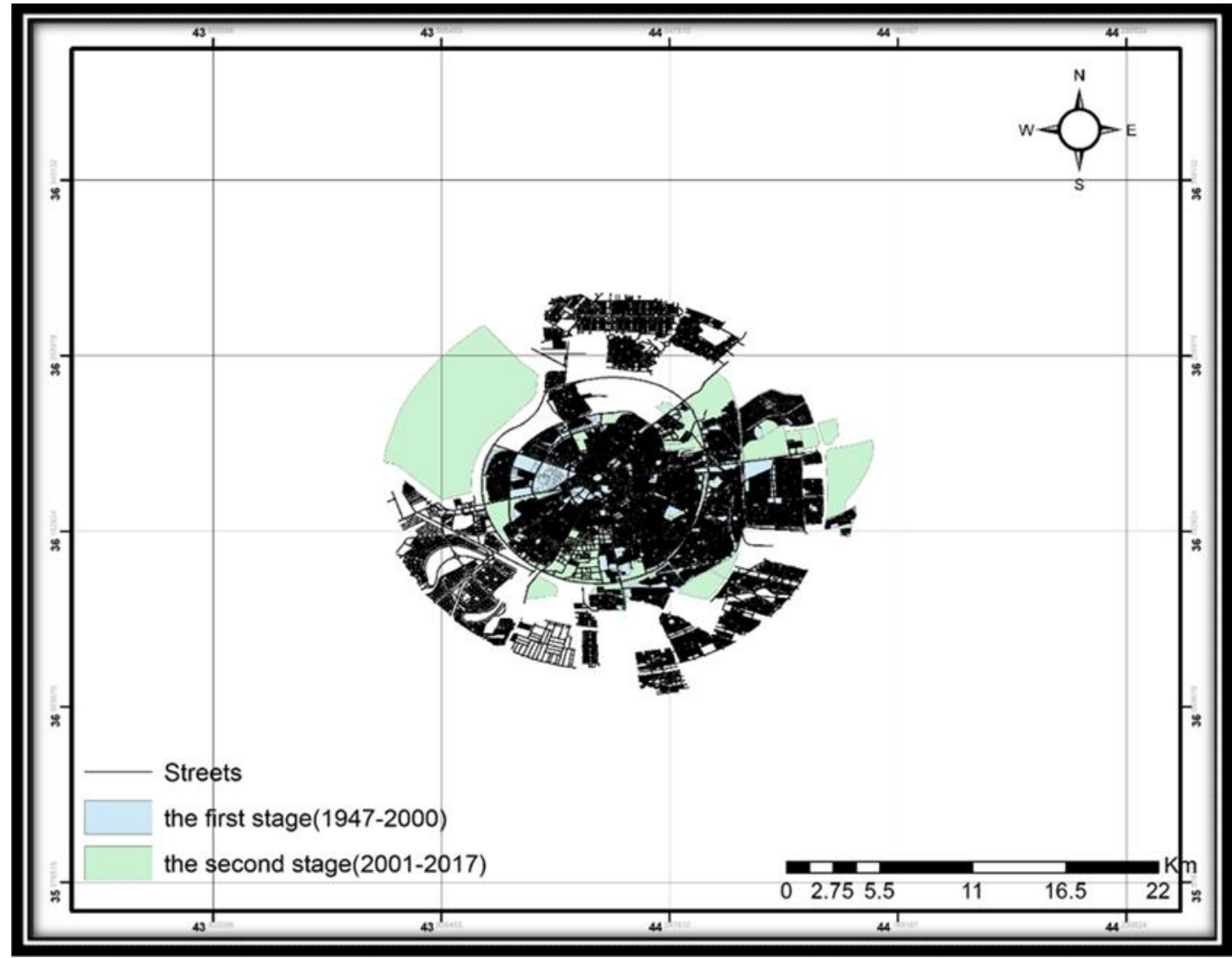

Reference; the work of the researcher depending on the Ministry of Municipalities,

Urban planning directorate, design basic map of the city of Erbil .

\section{3-FCTORS AFFECTING URBAN \\ EXPANSION OF ERBIL CITY}

The factors influencing the city's urbanization can be summarized in the following factors:

\section{1-1:Tobographical and Geological:}

The base of the city of Erbil belongs to the (palacitosin). It is composed of ancient and modern deposits ofzz. It was deposited during the rainy periods. Initially, the limestone, then the gravel, then the sand, the plains and the clay were deposited. The nature of the features of the surface of the location of the city of Erbil and the geological evidence in it have paved the way for the early stability of the city. The geological structure of the building materials (such as quarries, sand, clay and gravel materials) and to facilitate the process of building on them in different directions. The level of the earth and the lack of complexity in the parameters of the surface contributed to the spread of uses in different directions without hindering the path of any natural symptoms such as mountains or forests or bodies of water.(7) look at map no3; 
The topographic map of location of the study (map no 3)

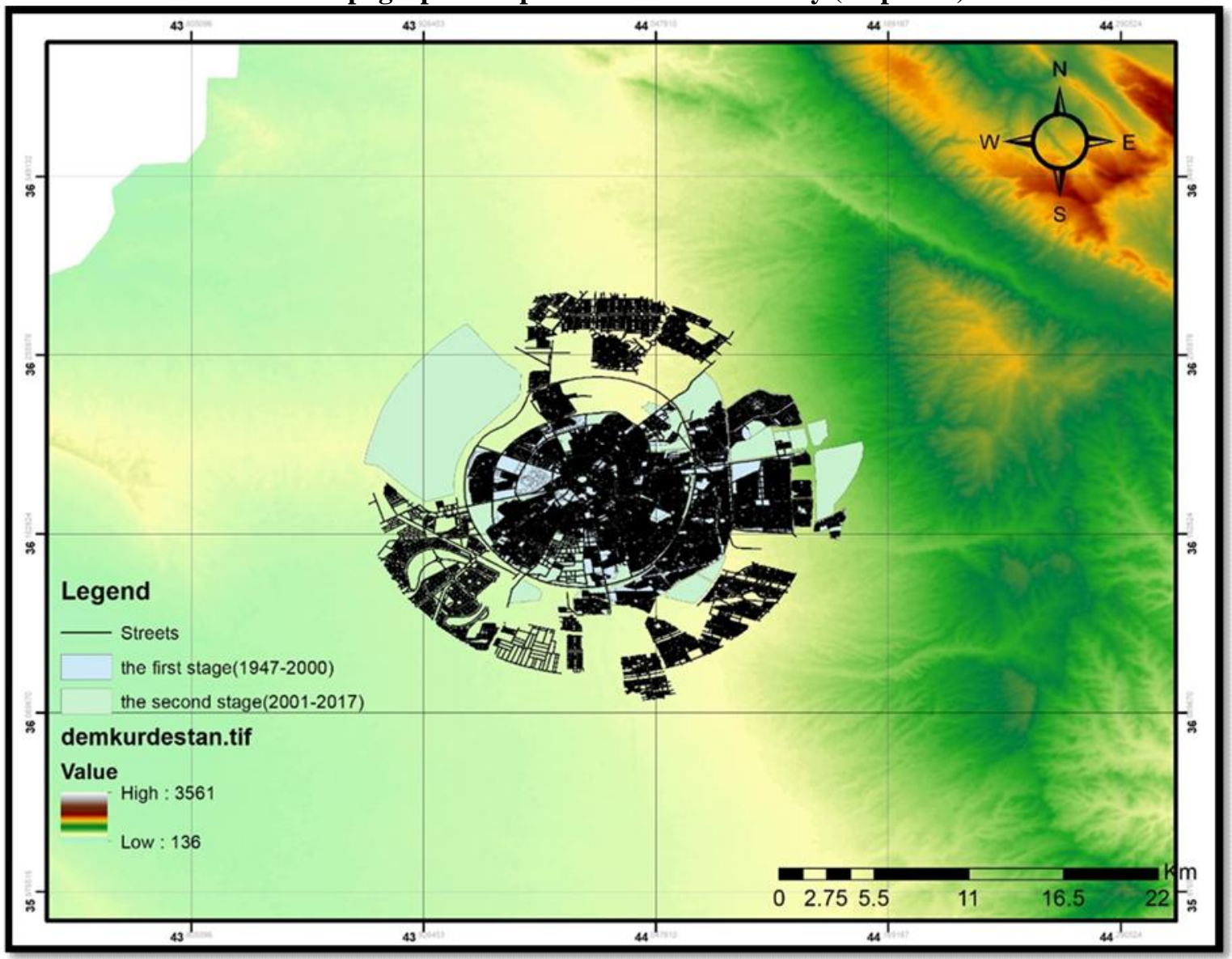

Reference; the work of the researcher depending on the area DEM and export program GIS.

\section{1-2: Demographic factor:}

Demographic factors play an important role in the expansion of cities. Urban growth is the main cause of the urbanization problem. Population growth is accompanied by increased demand for housing and other services, which leads to the expansion and growth of cities. The city has crawled towards the city limits.

It is noteworthy that the city of Erbil witnessed a significant increase in the size of its population due to the increase in birth rates for deaths or because of the increase in the population (migration), as the number of displaced families in various provinces of Iraq, Muslims and Christians, who headed towards the city of Erbil in the period (2005-2009 (More than fifty thousand people)(7), and contributed to these factors in the growth of population growth and continuity, and this indicates that the size of the population of the city is unstable and has undergone major changes, the city achieved a large population increase from (25487) people in the census (1947) to (549839) people in 2001 to 702812 in 2010. Diagram(no 1). 
Population growth of the city of Erbil through period(1947-2017) (diag no 1)

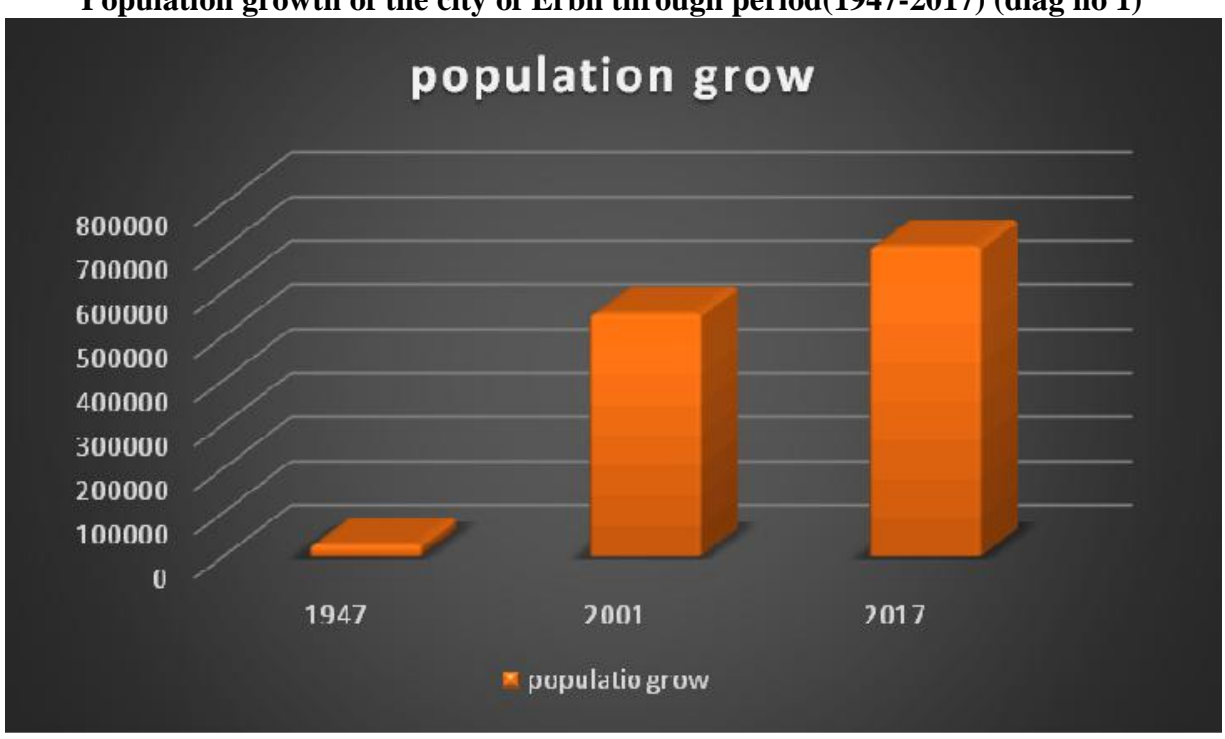

Reference; the work of the researcher depending on the Ministry of Municipalities, Urban planning directorate, part of GIS ,Erbil City Council Data, 2017, unpublished.

\section{1-3 Political Factor:}

The political factor has played a major role in the expansion of the city. It is arguable that this factor is one of the main reasons for the urban expansion of the city. The changes that occurred in Iraq in general and the city of Erbil, especially after 2003, made the city an attractive center for large numbers of the population. Of the various regions of Iraq, and the political stability in the region encouraged international companies in various disciplines to establish branches in the city of Erbil and to implement many investment projects in housing and construction, etc. The stable political situation also encouraged states to open their consulates in Erbil. The stable security situation has also positively encouraged civil society organizations and institutions to intensify their activities in the city.

\section{1-4: Economic Factor:}

The economic factors contributed to the urban expansion of the city through the spread of multiple residential projects in the agricultural areas of the study area. This expansion at the expense of agricultural lands led to a rise in the prices of the agricultural lands surrounding the city, encouraging their owners to sell them for residential or industrial purposes. And the type of agricultural land is also encouraged the owners of agricultural land to get rid of some types of land through the sale, the land of the third category or fourth does not give a large income to their owners because it is the Marsh land production is very few, compared to the income Which they receive when they sell or are exploited for residential or industrial purposes (8).

\section{1-5: Evolution of transport methods and means:}

The means of transport and its means are major factors that play a role in the expansion and development of the city of Erbil and through transport routes the city of Erbil able to extend its construction, and the change and development in the means of transport opened new areas for urban investment, especially outside, The predominant of which is agriculture, to other uses, the most important of which is residential use, and this factor has expanded the scope and extension of other uses.

The increase in the number of cars in the city of Erbil has led people to reach the outskirts of the city and live away from the center, as the number of vehicles of all types increased significantly. The number of registered vehicles of various types at Erbil Traffic Directorate in 2001 was 94442 vehicles, 2010), the number reached 336330 vehicles.(9)

\section{4- GEOGRAPHICAL DISTRIBUTION OF EXPANSION TRENDS IN ERBIL CITY}

The aim of this axis is to indicate the geographical distribution of the urban expansion 
trends witnessed in the city of Erbil, depending on the division carried out by the presidency of the city of Erbil, the city was divided during the period studied to (6) different municipalities in terms of area and population, as shown In Table
(1) and Map (2), in order to determine the extent of change in natural landscape and its transformation into human end-use due to land use for different uses (residential, commercial, roads).

Number of population, shops and total land use for Erbil City Municipalities (2017) Table (1)

\begin{tabular}{|c|c|c|c|c|c|c|}
\hline \multicolumn{7}{|c|}{ Total land use $\%$} \\
\hline total & services & Buildings & $\begin{array}{l}\text { Population/ } \\
\text { People }\end{array}$ & $\%$ of area Erbil & Number of stores & municipality \\
\hline 100 & 3760 & 624 & 107337 & 6981 & 10 & 1 \\
\hline 100 & 3815 & 6185 & 122494 & 25875 & 13 & 2 \\
\hline 100 & 4846 & 5154 & 86228 & 17842 & 9 & 3 \\
\hline 100 & 4178 & 5822 & 135044 & 13602 & 24 & 4 \\
\hline 100 & 4785 & 5095 & 104660 & 15113 & 13 & 5 \\
\hline \multirow[t]{2}{*}{100} & 4146 & 5854 & 147049 & 20584 & 11 & 6 \\
\hline & & & 712812 & 100 & 80 & total \\
\hline
\end{tabular}

Reference; the work of the researcher depending on the Ministry of Municipalities, Urban planning directorate, part of GIS ,Erbil City Council Data, 2017, unpublished.

We can view and analyze some facts through the table:

1. (4) occupies the first place for the number of residential shops, which is (24) locality, and comes third in terms of land use for housing and services by $58.22 \%$ and $41.78 \%$.

2. The Municipality of (2 and 5) comes second in terms of the number of shops that amount to (13) locality. Municipality (2) comes second in terms of land use for the purpose of housing by (61.85\%). 38.15\%).

3. The Municipality of (5) ranked fifth in terms of land use for housing by $(50.95 \%)$ and second place in terms of services by $(47.85 \%)$.

4. The municipality of (1) ranked fourth in terms of the number of shops which reach (10) locality. The area used for housing occupied the first place with $62.4 \%$. Services ranked fifth with $37,60 \%$.
5. The municipality comes in third place with 9 stores, occupying fourth place in terms of land use for housing by $51.54 \%$ and ranked first in terms of services by $48.66 \%$.

We conclude by presenting these facts as follows:

1. The geographical distribution of the urban expansion witnessed by the city of Erbil headed primarily towards the outskirts of the city, ie Baldata (4 and 6) to the east and west.

2. There is no regular geographical distribution in terms of the distribution of the population on the basis of the area owned by each municipality, for example, the population in the municipality (2) arrived (122494) and constitute an area (25.8\%) of the city of Erbil, The population of the municipality (4) (135044 inhabitants) on the area constitute (13.6\%) of the area of the city of Erbil, and this means that the factor of the area does not correspond to the size and population. 


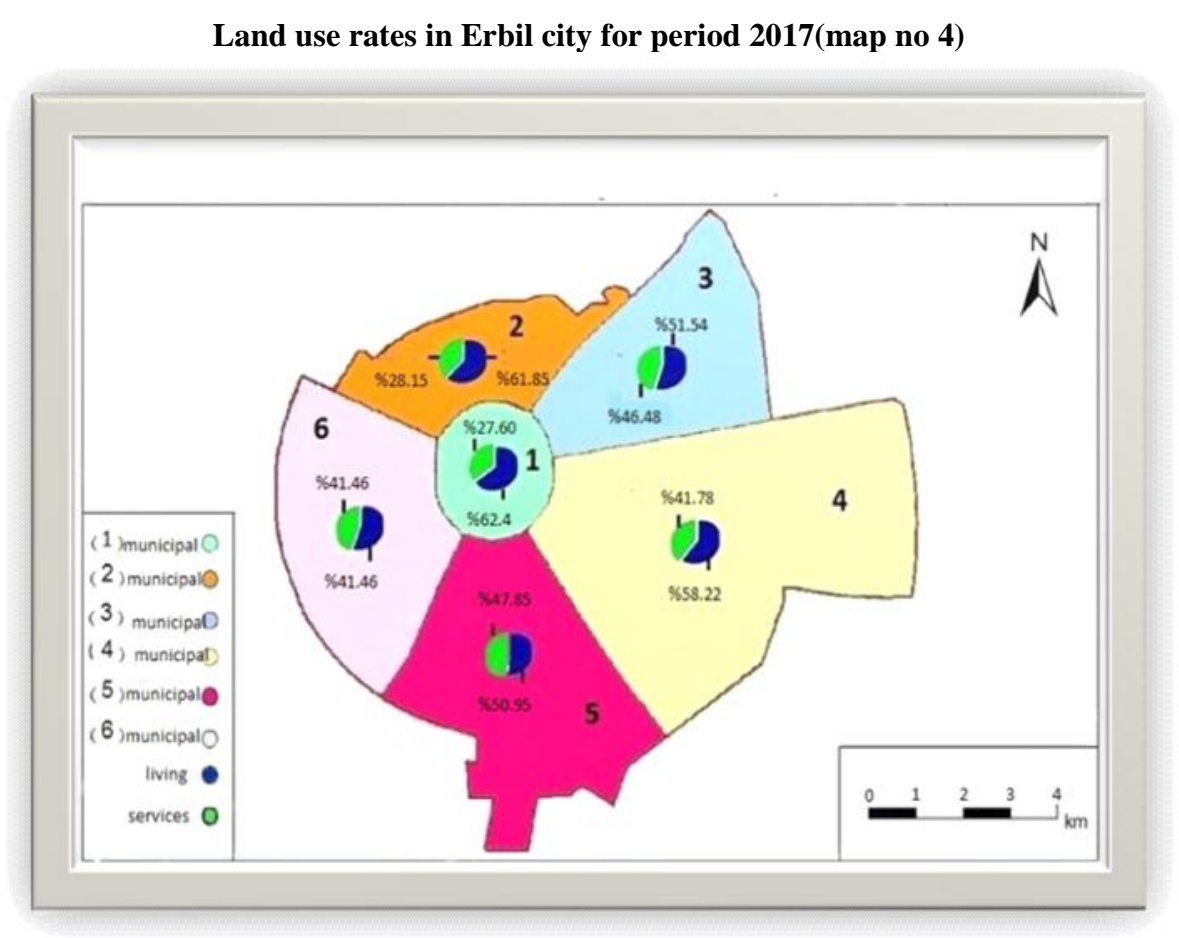

Reference; the work of the researcher depending on the dates tables ago, number (1),2017

\section{5-THE MOST IMPORTANT ENVIRONMENTAL PROBLEMS CAUSED BY THE URBAN EXPANSION OF THE CITY}

\section{5-1: Climate Consequences:}

\section{A - High temperature in the city:}

The city has a distinct climate that differs from the climate of the neighboring rural areas, due to different characteristics of the natural and human city. The cities are densely populated and have similar properties such as the large number of inhabitants, and the wide spread, but vary in composition in terms of design of buildings and streets and the use of land, and these differences in the impact of urban climate, and depends on the degree of impact of cities in the elements of climate on several factors, It has been noted that the increase in the population leads to high temperature in the city and causes energy sources from factories and cars and the use of heating devices to increase temperatures, and affect the materials used in the construction of city facilities (asphalt, cement, bricks, rock, In the city's climate because they have a large absorptive capacity of energy, which contributes to the warming of the city. All this leads to the formation of thermal island $(*)$ in cities (9).

With regard to Erbil, the increase in the number of cars, the increase in the population and the increase in the area of built-up areas, together with industrial activity, have contributed greatly to climate change and heating.

\section{$B$ - The rise of the phenomenon of dust storms:}

The location of the city of Erbil within the region of semi-dry climate on the one hand, and proximity to the dry climate region from the south and west on the other hand as well as its continental location causes:

The city is exposed to dust and dust storms from the south and west, especially in the summer and autumn. The figures indicate an increase in the percentage of dust storms in the city during the years 2007-2017. The percentage of dust and dust in 2007 was $19 \mathrm{mg} / \mathrm{m} 3,51 \mathrm{mg} / \mathrm{m} 3$ and in 2017 reached $171 \mathrm{mg} / \mathrm{m} 3 .(10)$

The frequency of drought (the decrease in rainfall compared with the monthly and annual rates) in the city, as shown in Table (2) 
Annual rainfall in Erbil station for the period 2001-2017 (table no 2)

\begin{tabular}{ll}
\hline Annual rainfall/mL & years \\
\hline $\mathbf{3 2 7} 3$ & 2001 \\
\hline $\mathbf{4 6 3 4}$ & 2002 \\
\hline $\mathbf{4 9 6 3}$ & 2003 \\
\hline $\mathbf{4 5 7 7}$ & 2004 \\
\hline $\mathbf{2 9 7 5}$ & 2005 \\
\hline $\mathbf{5 1 4 6}$ & 2006 \\
\hline $\mathbf{2 7 3 4}$ & 2007 \\
\hline $\mathbf{2 9 7 5}$ & 2015 \\
\hline $\mathbf{3 1 1 9}$ & \\
\hline $\mathbf{2 6 0 , 4}$ & 2016 \\
\hline
\end{tabular}

Reference: Ministry of Transport and Communications, Directorate of Aeronautics, Erbil station, data on the amounts of rainfall of Erbil station for the period (2001-2017), unpublished data.

The highest rainfall in 2006 was $(514.6 \mathrm{~mm})$, while the lowest rainfall recorded in 2017 was $(260.4 \mathrm{~mm})$, which means That the amount of rainfall that decreased in the year (2017) reached (254.2 $\mathrm{mm})$, compared with the year (2006). This indicates that the area of study is experiencing climatic changes resulting in many environmental problems

\section{5-2: Waste problem in the city:}

The amount of daily waste is generated in Erbil from many different sources. These sources are in residential shops, commercial areas, parks, parks, industrial zones, construction waste, buildings, facilities, institutions and slaughterhouses. The size and scope of these sources vary from municipality to municipality, which is reflected in the difference in the quantity of waste generated from each source in each Municipality of Erbil.

Domestic waste constitutes the largest percentage of waste in the city. The daily average of these wastes is 806 tons and constitutes about $67.17 \%$ of the total waste in the city. The percentage of waste in the east of the city (1400) tons, and West (1600) tons per day.

Commercial waste in terms of quantity and percentage of its contribution to the total amount of waste for the city of Erbil ranked second, with a daily average of 328 tons, constituting $27.33 \%$ of the city's total fat.(11)

We conclude from this that the increase in the contribution of household waste and commercial markets and the decrease in the proportion of other sources of waste is due to:
Man, his activities and his daily efficiency are the source of waste.

Residential and business functions are the most important functions of Erbil. This shows the percentage of occupied areas in both residential use and commercial use of the total built-up area in the city

\section{5-3: noise problem:}

The problem of noise is another problem in the city of Erbil, because of the expansion of the city, because this increase in the population needs to build new shops and neighborhoods and thus grow the housing function and expand, In addition, the diversity of transport means very much increase the problem of noise, because the width of many of the city's streets is not commensurate with the number and density of cars, because of the large number of cars passing by, as is known That the width and breadth of the streets lead to the flow of traffic, and the narrow streets

Which determines the flow of traffic, leading to the creation of traffic jams that increase the incidence of noise, as well as the frequent use of generators as a result of increasing population and the need for electricity.

Noise can be defined as "any unwanted sound that causes discomfort and harm to the human being". It is noticed that noise is a source of disturbance to people and causes many diseases if they exceed the safe limit and reach the dangerous level. In Erbil, the noise has exceeded the safe limit and reached some places such as the teachers' At night, and (99) in the morning in the place of justice (12), 
From here it can be said that the noise in the city of Erbil turned the phenomenon into a major environmental problem, suffer from the city and increase the intensity and risks at high rates during the coming period.

\section{5-4Water Problem:}

At present, the city relies on securing its water needs on groundwater. The groundwater in the Erbil Plain is one of the most important sources of water. It supplies the city's population with a large quantity of water. Water consumption in Irbil alone is more than $60 \%$.

The use of groundwater in the study area has increased and the number of wells drilled in the last period has increased as a result of the increase in the population and the increase in their needs and the diversity of their requirements compared to the previous periods. This is evidenced by statistics. More than 2500 wells were drilled in 2008, (2017) to (6730) wells in the city of Erbil.

It can be said that in just two years the number of wells drilled increased to about (4230) wells. This has led to a decrease in groundwater levels. For example, the highest level of the well of the village of Einqawa $(29.5 \mathrm{~m})$, while the lowest annual level was $(11.5 \mathrm{~m})$ in 2009 - 2017, The highest level of well $(19.5 \mathrm{~m})$ and the annual rate dropped (9.5 m) in 2006 - 2007. The Siddawa well reached the highest level $(32.5 \mathrm{~m})$, while the lowest annual level reached $(15.3 \mathrm{~m})$ in 2008 2017 (13).

The widespread use of water in response to the needs of the urban population will lead to the depletion of groundwater reserves in the region and will expose the region to an environmental disaster if this problem is not addressed in a timely manner. Moreover, low water levels make water polluted and a source of many diseases.

\section{5-5 Political factor;}

Political actors play an important role in the expansion of urban areas, and this can be reflected. It may have been several forced dissidents by the Iraqi government during the period (1975-1989) in the portrayal of this page Erbil (Zebarians, Barzani, Barrostists, Sherwaniens, Mizorians and Balkans) and most of these areas have become centers that either have relevance or that It has reached pre-school (3) to the most important complexes that have become urban centers within the area forming part of the center. There is no doubt that the establishment of all these residential complexes at the time and turning them into urban centers affected the expansion of the urban area and the increase in the number of urban centers in the study area. Erbil has attracted large numbers of immigrants from central and southern Iraq because of security. 
The most important compound forced in the study area table no3

\begin{tabular}{|c|c|c|}
\hline Name of compound forced & (area) & year of establishment \\
\hline Qadisiya & Khostab & 1976 \\
\hline Mezory & & 1979 \\
\hline Topzawa & Rezgary & $1987-1978$ \\
\hline Gawragozk & Gawragozk & 1987 \\
\hline Daratow & Daratow & 1989- 1987 \\
\hline Bensalaw & Bensalaw & 1987 \\
\hline Bhrekah & Bhrekah & 1987 \\
\hline Perzen & Bhrekah & 1978 \\
\hline Shawes & Khasnazan & $1986-1975$ \\
\hline Khsnazan & Khasnazan & 1979 \\
\hline
\end{tabular}

Referncses: From the work of the researcher based on: 1 - Mohammed Abdullah Omar Alhalhouni, Geographical

Analysis of Rural Settlement in the Kurdistan Region of Iraq, An Applied Study of Arbil Governorate, Kurdistan

Center for Strategic Studies, Sulaymaniyah, 2005, pp. 138-143

2 - Personal interview with the heads of the municipality of the areas of study 10-5-2018.

The poor security situation in the central and southern governorates of Iraq after the fall of Saddam Hussein in 2003.

And the lack of political stability was the cause of displacement of large numbers of residents of these provinces of different nationalities and to the provinces of the region and the study area, and these contributed to their role in the pressure on agricultural land in the study area.

\section{5-6 Economic and behavioral factors;}

There is a behavioral reason for the desire of the inhabitants of major cities to live in the suburbs outside the city, as well as the economic factor of the high prices of agricultural land surrounding the city encourages the owners to sell for housing or industry as well as the material factor tempts owners of agricultural land under the city to sell Their land for non-agricultural purposes. The quality factor of agricultural land also encourages owners of agricultural land to dispose of certain types of land by selling. The land of the third or fourth type does not give a large income to their owners compared with the income that She got him if he sold or exploited by residential or industrial purposes .

\section{5- The shrinking of agricultural land and the emergence of desertification:}

Agricultural land is shrinking as a result of human development of urban projects and the opening of new roads on agricultural land, as well as the establishment of residential complexes on them, thus paving the way for desertification.
The government has played a major role in activating this problem. Since 2001-2017, the government has tried to expand the city of Erbil by distributing plots of land to various sections of the city,

A- Distribution of land plots to the population as follows:

- Distribution of (1000) plots of land (200 m 2).

- Distribution of (7500) plots in the locality of Hazarok (Zilan) in the year (2003) and (14500) land in.(2004)

- Distribution of (1100) plots in the locality (94) Badawah.

- Distribution of (3250) plots in the area (Badrawani) area (250 m 2).

B- The distribution of land plots to the families of the martyrs: The Government of the Territory gave a grant to the families of the martyrs. The grant was distributed (1450) plots of land area ( $250 \mathrm{~m} \mathrm{2}$ ), and the name of the camp (martyrs).

G-The establishment of several modern housing complexes by the private sector companies, and the provision of facilities by the government in terms of giving them land for the purpose of building residential units, such as the establishment of the English village on 26 dunums, and the village of happy Land on an area of (200) The Italian village, the city of Manara, Laouane, Lainde, Ashti, Hiran, etc.(14)

The total area used for housing in (2001) was (3504.5) km, whereas in 2017 it reached (3961.12) $\mathrm{km}$. 
As mentioned in the above, we can say that the city of Erbil witnessed a rapid and significant expansion, especially after the liberation of Iraq in 2003, and later became the capital of the Kurdistan Region, and the presence of all ministries and government institutions, which led to attracting large numbers of the population and their march towards the parties The number of plots distributed during the period 1958-1990 was 45,376 . The number of plots distributed between 1990 and 2017 increased to 83031, ) Plots of land ranging between (200-600 $\mathrm{m}$ 2).(15)
We can say that the implementation of the basic design of the future with the basic plan of the city of Erbil until 2030, designed by the Ministry of Municipality, leads to the transformation of a large area of agricultural areas with fertile soil to urban areas - map No. 5, And the potential for deepening and exacerbating the phenomenon of desertification is significant due to the increase in the population in the future. The increase in the population's needs for food (plant and animal) exacerbates the problem, because it creates additional pressure on the lands of the study

area.

The proposed urbanization of the city of Erbil in the year 2030 and its impact on the area of Erbil plain map no 5

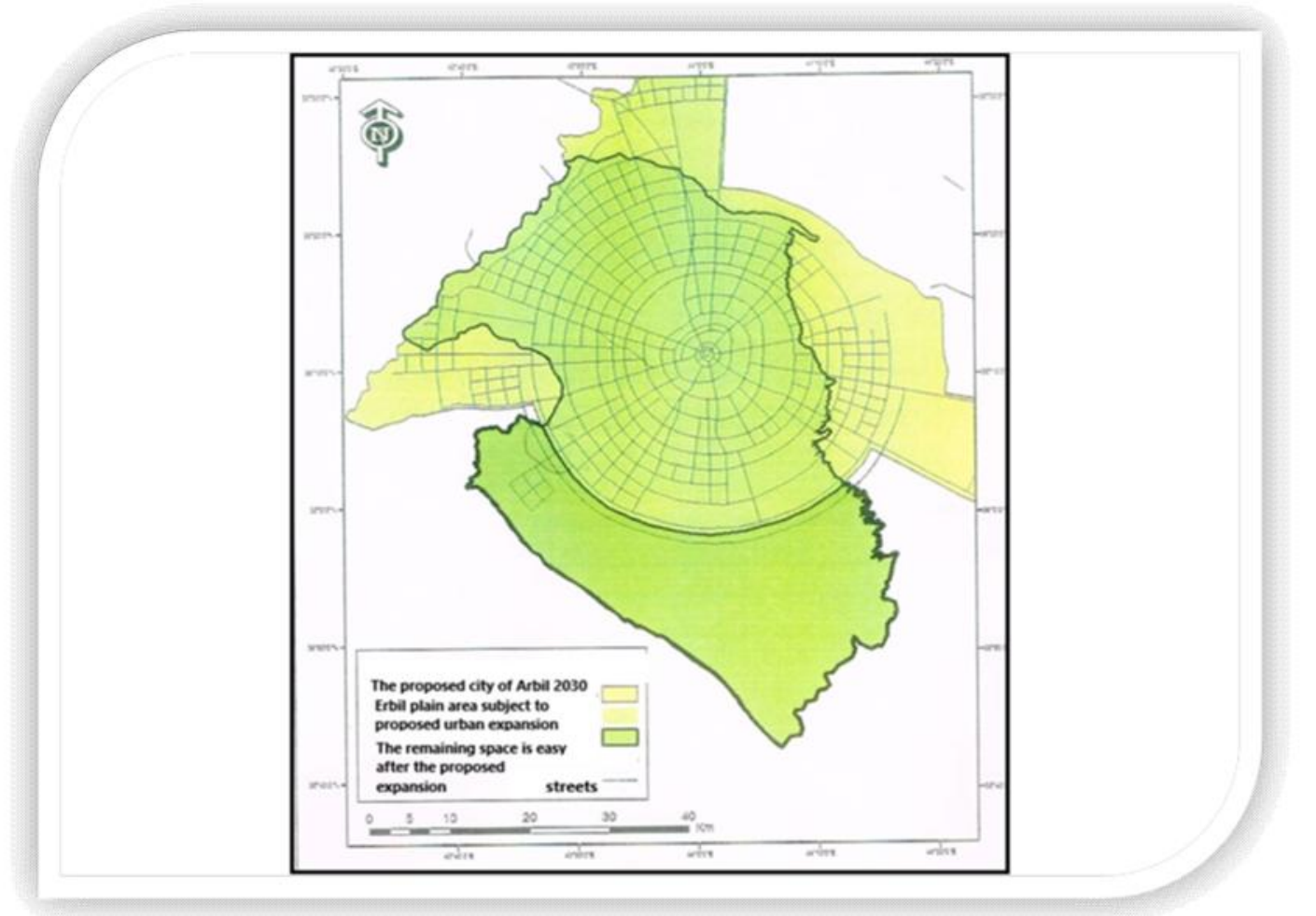

Reference of the table: Based on: Government of the Kurdistan Region of Iraq, Ministry of Municipalities and Tourism, Division of Urban Planning, Department (GIS), data area of the municipalities of Erbil, , unpublished. 


\section{Future design of the city of Erbil until 2030 map no6}

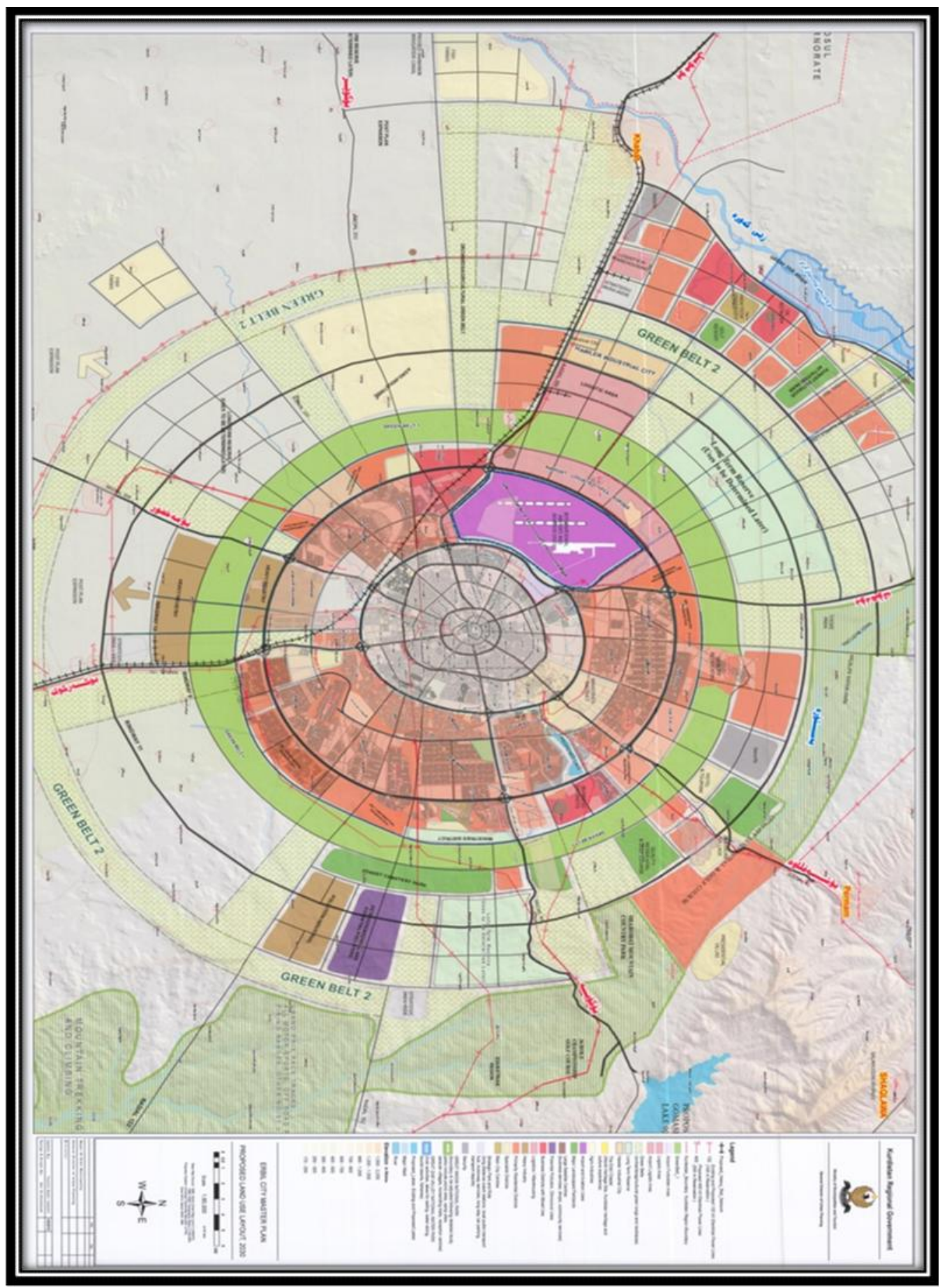

References ;Kurdistan Region of Iraq, Ministry of Municipalities and Tourism, Directorate of Engineering and Urban Planning, Design Department. 
6-DEVELOPMENT POTENTIAL AVAILABLE IN THE CITY OF ERBIL PERIOD 2010-2030;

\section{6-1 Private investments:}

Investment is one of the most important economic variables that play an important role in the overall economic activities.
The distribution of investments in the city of Erbil was not planned, as concentrated in the city of Erbil (92.43\%) during the period 2010-2030

And require the need for tourist facilities, modern markets and entertainment services because of the concentration of foreign embassies and ministries and the influx of tourists.

See Table (2)

The volume of private investments in the city center of Erbil and outside between 2010-2030

\begin{tabular}{lll}
\hline Percent $\%$ & Investment amounts(dollar) & Name of center \\
\hline $\mathbf{9 2 . 4 3}$ & 8895709478 & City of Erbil \\
\hline $\mathbf{4 . 0 2}$ & 387304510 & Out of city \\
\hline
\end{tabular}

References; The researcher worked on: Kurdistan Investment Authority, Planning, and unpublished data

\section{6-2Natural Resources:}

The city of Erbil contains oil sources at its outskirts, and the production capacity is about (100) thousand barrels per day, As for the minerals in the city are iron, gold and zinc, ranging between $15-60 \%$ of the total raw materials in Iraq.

6-3Agriculture:

Agriculture in this city depends on rained agriculture due to the heavy rain in it, in addition to a difference in the distribution of rain.

We find that the proportion of orchards in the center of Erbil is low due to the creeping of urban housing in addition to harsh climatic factors.
Natural forest areas are concentrated in the outskirts of Erbil. These areas can be invested in tourism and pastures in the development of the city's animal wealth.

\section{6-4Industry:}

Erbil city center occupies the first position for the number of workers and industries, due to the availability of services and infrastructure, which reduces the cost of production.

In addition to the availability of production inputs and large markets. Look at map no 6 .

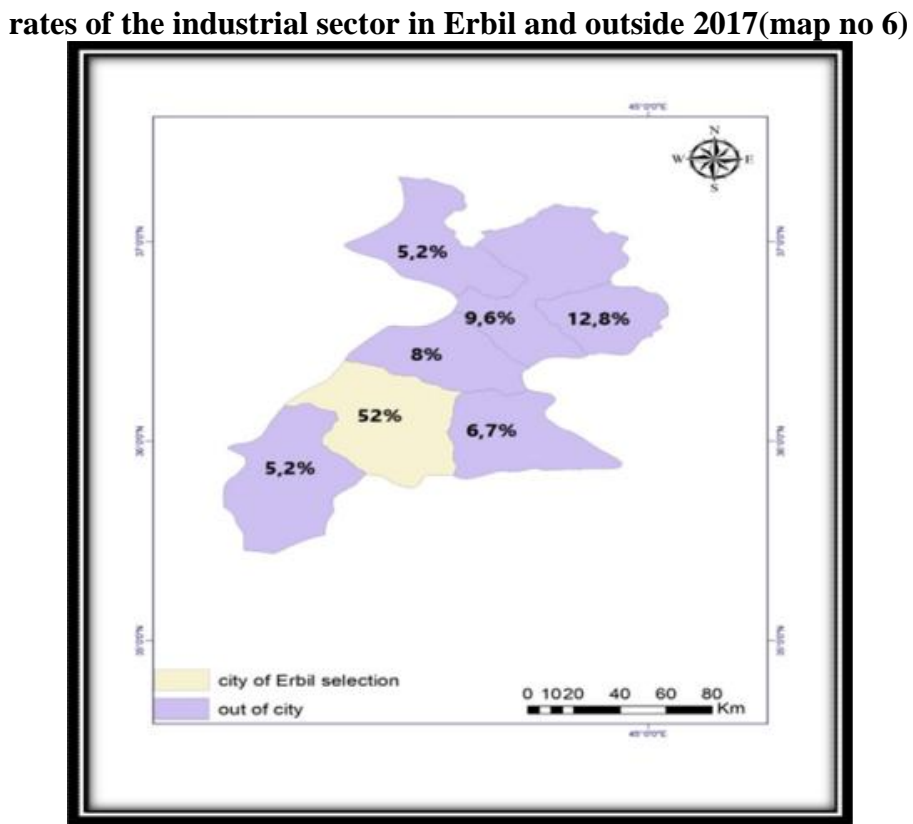

References: Ministry of Municipalities and Tourism, Directorate of Information and Marketing, Tour Guide, 2017 


\section{6-5tourism:}

That the Kurdistan contains the resources of tourism attractions, especially the city of Erbil because of the containment of ancient religious and archaeological sites and tourism services of hotels, gardens, swimming pools and some natural places,

The number of tourists in the center of the city of Irbil for the year 2030 (350000) tourists from Iraq and abroad, and the number of hotels (95) hotels (16).

\section{Final: Ways to address the problem of urban expansion and urbanization in the plain of Erbil;}

The study showed that the Erbil Plain suffers from the problem of urban expansion of Erbil and other urban centers within it. This problem has reached the extent that the area of

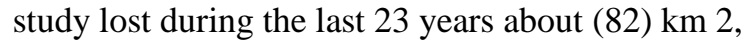
(32753) dunums of its area and in the implementation of the future design of the city of Erbil until 2030 will remain from Erbil plain $(37 \%)$ of its area.

We face a serious problem that requires serious and rapid processing. These treatments should be based on the factors that cause the problem, those described in the previous pages, and on benefiting from the successful experiences of peoples and countries that preceded us in dealing with similar problems in their countries. Urban expansion as a phenomenon can not be stopped permanently, but it can be reduced and slowed down through the following ways:

1- Vertical expansion instead of horizontal (at least in areas allocated to public services, educational and health, with guarantees to ensure success).

2- Exploitation of non-arable land for building urban projects instead of arable land or fertile soil

3- Attention to rural areas and reconstruction and supply services to reduce the adverse migration

4- interest in the agricultural sector and encourage farmers to agriculture

5- Issuing legislation to prevent migration from other Iraqi provinces to the city of Erbil and limit its expansion.

6- Prevent the establishment of plants and buildings of those private companies that occupy large areas at the expense of agricultural land.
7- make adjustments to the future design of the city of Erbil and think about the establishment of new cities in areas far from the city of Erbil, the land of agricultural importance as large as Erbil easier to allocate a larger share of the design specified for agricultural uses.

8- Reduce the granting of licenses to build housing projects on land suitable for agricultural production.

9- The distribution of industries and economic projects and services on the cities of the province and the region and not limited to the central city (Erbil) because its urban expansion responsible for one-third of the total urban expansion in the study area during the period between 1987-2010.

10- Benefit from the successful experiences of other countries that have been able, as a result of scientific planning proper to reach some solutions to the problem of urban encroachment on agricultural land, including:

- Develop policies related to the management and use of land within and around cities, which take into account the extension and growth of residential communities and the development of laws regulating the boundaries of cities.

- Establishment of specialized institutions in the urban organization within the city to control and control the organization and extension of construction.

- Reducing the horizontal extension of urbanization at the expense of agricultural land by expanding the vertical extension of residential buildings.

- Good planning of the sites of industrial establishments so as not to be at the expense of arable land

- To guide future urbanization to non-productive areas.

11- enact the necessary legislation that would put an end to urban expansion and follow up its implementation to achieve the desired goal of slowing urban expansion in Erbil plain, which is the food basket for the province and the Kurdistan Region of Iraq.

\section{RESULTS}

The study reached a set of results summarized in the following points:

1. The city of Erbil lies in the middle of the fertile Erbil plain. The land is located in the city's location from the northeast to the southeast and 
descends in the city center to $(412 \mathrm{~m})$ above sea level except for the fortress of Erbil.

2. The city of Erbil occupies a transitional position between the rolling plains region on the south and the mountainous region of the north, north and east, resulting in interaction and friction between two different economic and economic environments due to its presence in the mountain slopes.

3. The city of Erbil witnessed a significant urban expansion at the expense of the surrounding agricultural lands, and the process of expansion proceeded at many different stages.

4. There are many factors behind the process of urbanization in the city, including the geological structure, the demographic factor, the economic factor, the political factor, and the development of means of transport.

5. The city of Erbil was divided into (6) different municipalities in the number of population and area, and the urban expansion witnessed by the city of Erbil was to the east and west in the first place.

6. This expansion resulted in several environmental problems, including the increase in the city's temperature, the increase in dust storms, the low rainfall, the problem of groundwater shrinkage, the problem of waste, the problem of noise, and the problem of shrinking agricultural land.

7. The existence of tourist potential in the city of Erbil, but needs an infrastructure to reach the integration of tourism in the region.

8. The best style of spatial development in the city of Erbil is an integrated development pattern.

\section{Recommendations}

Based on the findings of the study, we recommend the following:

1- $\quad$ Produce the necessary legislation and laws to put an end to such large urbanization and prevent the construction of housing projects on all lands. Successful law enforcement requires that many ministries participate in the implementation of laws, such as ministries of agriculture, planning and municipal affairs.

2- The government must take into account the city's condition and nature, in the sense that the future urban expansion towards the nonproductive areas, those areas have a rocky land is not suitable for agriculture, and the projects are built on them instead of building on land for agriculture.
3- More attention to green spaces, and expansion of the patch, because the city of Erbil urgently need to green areas, because the green areas in the city is small compared to the size of the city and its population.

This is a responsibility of the state directly. The government should supervise these projects. These projects should be in accordance with sound environmental planning, consider the principle of clean energy, and fit the environment of the region.

\section{SCIENTIFIC REFERENCES}

1. Al - Naqshbandi,A . Geographical Analysis of Green Areas in Erbil City Using GIS Techniques, GPS, Zanko Magazine, Issue 50: 371.

2. Al-Naqshbandi, A Geographical Analysis of Green Areas in Irbil, former source: 401.

3. Ali , A, Applied Climate, Amman, First Edition, 2010: 139.

4. Excerpt from a previous source: 39.

5. Hashem ,Al , City of Arbil. Study in Urban Geography, Directorate of Dar Al Kutab for Printing and Publishing, Mosul University, Mosul, 1987: 42.

6. Kurdistan Regional Government of Iraq, Ministry of Interior, Erbil Traffic Directorate, Vehicle Registration Division, unpublished data.

7. Kadir, F. Minister of Higher Education and Public Administration, Bau Dabash Bony Danishwan and Kareetri, Chairperson of the Board of Directors of the Board of Directors of the Board of Directors of the Board of Directors of the Bank.

8. Rathan ,S, Geographical Analysis of Environmental Problems in Erbil Plain, Master Thesis Presented to the Faculty of Arts - Salahuddin University, 2012: 165.

9. Sakar,B, Residential Patterns in Erbil, Master Thesis submitted to the Faculty of Arts, 2003: 50.

10. Sakar Bahaauddin Abdullah, ibid.

11. Kurdistan Region of Iraq, Ministry of Municipality and Tourism, Erbil Municipality Directorate, Design Department of Erbil City (2010.(

12. Salah, H and Saqr Bahaa Al - Din, The Role of Compressive Areas in the Directions of Urban Expansion of Erbil City, Zanko Magazine, Issue (47) - 2010: 239. 
13. (*)Urban growth: the increase in the urban population. The increase is mainly based on rural-to-city migration and on the increase in natural population.

14. Salah, H and Saqer Bahaa 'al - Din, previous source.

15. (*) Heat Island is the unique phenomenon of cities, where the temperature is much higher than the surrounding areas of the city and the countryside, where urban structures store heat during the day and then slowly release.

16. Kurdistan Regional Government of Iraq Ministry of Municipalities and Tourism, Directorate of Information and Marketing, Tour

Guide,

2017.

الخلاصة

تهدف هذه الدراسة الى تتبع وتحليل اتجاهات التوسع المساحي للمراكز الحضرية وأثارها البيئية خلال فترة

الدراسة، والسعي لوضع توصيات مناسبة للجهات المعنية من أجل النهوض بواقع تلك المراكز الحضرية و تقليل اثارها السلبية على البيئة.

و تتلخص اهمية الدراسة في اظهارها لحجم التوسع الحضري في منطقة الدراسة و التعرف على اسبابه، مما يستدعي ذلك تحديد انواع الاراضي و استخداماتها المثلى لتقليل الاثار السلبية لمشكلة التوسع الحضري. وقد جاءت الدراسة ضمن ثلاث مباحث فضلا عن المقدمة و الاستنتاجات و التوصيات، استهل المبحث الاول بالتطرق الى تعريف بمنطقة الدراسة و المصطلحات المتعلقة بموضوع. واهتم المبحث الثاني بإظهار التوسع الحضري للمراكز الحضرية مدينة اربيل وفق مراحل زمنية متباينة .فيما تناول المبحث الثالث دراسة

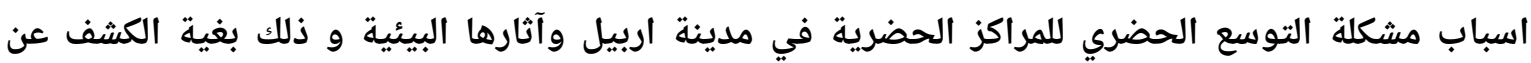
مراحل التوسع الحضري و اثارها البيئية. 